\title{
Kajian Terhadap Gerakan Kebangkitan Epistimologi (Epistimological Movement) Tacit Knowledge Michael Polanyi
}

\author{
Atik Rosanti ${ }^{1}$, Nanat Fatah Natsir ${ }^{2}$, Erni Haryanti ${ }^{3}$ \\ 1,2,3Universitas Islam Negeri Sunan Gunung Djati Bandung, Indonesia \\ E-mail:rosantiatik@gmail.com,nanatfatahnatsir@uinsgd.ac.id, erni hk@uinsgd.ac.id
}

\begin{abstract}
Article Info
Article History

Received: 2021-11-20

Revised: 2021-12-15

Published: 2022-01-09

Abstract

This study describes the study of Michael Polanyi's epistimological movement of tacit knowledge. The method used in this study uses a library research method or approach. The results of this study indicate that philosophy is very important for human life because it can solve various life problems. As a result of the rapid development of science has given birth to many new understandings. The presence of a new

Keywords:

Epistemology;

Tacit Knowledge;

Michael Polanyi. understanding as a criticism of the previous understanding. Polanyi criticizes Positivism because it sees science too much from the aspect of objectivity. His criticism resulted in a work entitled "Undisclosed Facets of Science". The relevance of Polanyi's thoughts to educational institutions through internal policies in an effort to improve school quality. Schools need to provide autonomy and flexibility to homeroom teachers to organize classes in an innovative and creative way in order to create productive and comfortable classes so that students are able to develop and bring out their hidden potential. Here are some efforts that can be made by homeroom teachers in class management, including: First, regular homeroom meetings and parents of students. Second, Joint Class Arrangement. Third, Build Class Warmth. Fourth, Doing Quality Time Together. Fifth, Homeroom Counseling Services. Lastly, Coordination with Various Parties.
\end{abstract}

\begin{tabular}{l}
\hline Artikel Info \\
\hline Sejarah Artikel \\
Diterima: $2021-11-20$ \\
Direvisi: $2021-12-15$ \\
Dipublikasi: $2022-01-09$
\end{tabular}

Kata kunci:

Epistimologi; Tacit Knowledge; Michael Polanyi.

Abstrak

Penelitian ini menjelaskan tentang kajian terhadap gerakan kebangkitan epistimologi (epistimological movement) tacit knowledge Michael Polanyi. Metode yang digunakan dalam kajian ini menggunakan metode atau pendekatan kepustakaan (library research), Hasil penelitian ini menunjukkan bahwa Filsafat sangat penting bagi kehidupan manusia karena dapat memecahkan berbagai persoalan kehidupan. Akibat pesatnya perkembangan ilmu pengetahuan telah banyak melahirkan paham baru. Kehadiran paham baru sebagai kritik bagi paham sebelumnya. Kritik Polanyi terhadap paham Positivisme karena paham tersebut terlalu melihat ilmu pengetahuan dari asplek objektivitasnya semata. Kritiknya mengahsilkan sebuah karyanya yang berjudul "Segi Tak Terungkap Ilmu Pengetahuan". Relevansi pemikiran Polanyi pada lembaga pendidikan melalui kebijakan internal dalam upaya peningkatan mutu sekolah. Sekolah perlu memberikan otonomi serta keleluasaan pada wali kelas untuk mengatur kelas secara inovatif serta kreatif agar terciptanya kelas yang produktif dan nyaman sehingga peserta didik mampu mengembangkan dan memunculkan potensinya yang masih tersembunyi. Berikut beberapa upaya yang dapat dilakukan oleh wali kelas dalam manajemen kelasnya, diantaranya: Pertama, Pertemuan rutin Wali Kelas dan Orang Tua Peserta Didik. Kedua, Penataan Kelas Bersama. Ketiga, Membangun Kehangatan Kelas. Kempat, Melakukan Quality Time Bersama. Kelima, Layanan Konseling Wali Kelas. Terakhir, Koordinasi dengan Berbagai Pihak.

\section{PENDAHULUAN}

Filsafat ilmu merupakan turunan dari ilmu filsafat yang sering kali digunakan sebagai pijakan dalam pengembangan ilmu pengetahuan ilmiah melalui pendekatan epistimologi (Efendi, 2020). Ilmu pengetahuan hadir semenjak munculnya kehidupan manusia di bumi hingga menjadi ilmu atau ilmu pengetahuan. Hal tersebut di karenakan adanya hasrat serta keingintahuan manusia untuk memenuhi kebutuhannya yang terus meningkat dan berkembang
(Irwansyah, 2021), Yunani selalu menjadi acuan ilmu pengetahuan secara teoritis hal tersebut dikarenakan yunani merupakan tempat bersejarah awal lahirnya peradaban dan lahirnya filsafat secara utuh. Filsafat yunani adalah penyempurna pradaban Mesir dan Mesopotamia yang telah ada ribuan tahun sebelumnya. Kehadirannya sangatlah berharga bagi ilmu pengetahuan karena menjadi landasan berfikir untuk menggali ilmu pengetahuan dan menjadi pembuka ragam disiplin ilmu pengetahuan 
lainnya (Karim, 2014), tidak mengherankan apabila epistimologi beranjak menjadi disiplin ilmu yang bersifat evaluatif, normatif dan kritis. Evaluatif dalam penilaian kebenaran yang dapat dipertanggungjawabkan. Normatif pada pemberian norma kebenaran pengetahuan. Kritis adalah memberi banyak mempertanyakan dan menguji cara maupun hasil kegiatan manusia (Sari, 2020). Oleh karenanya filsafat ilmu terus berkembang tanpa henti merasuki ranah ilmiah untuk mencapai kebenaran atau kenyataan yang tidak pernah ada akhirnya untuk difikirkan dan diterangkan (Rofiq, 2018).

Dalam pesatnya perkembangan ilmu pengetahuan telah banyak melahirkan paham baru. Satu paham hadir untuk mengkoreksi paham lainnya. Kemunculan paham Positivisme memang membuat ilmu berkembang sangat pesat namun melupakan filsafat sebagai induknya. Menurut Hadi dalam (Na'im, 2021) bahwa selain itu paham positivisme terlalu memaksakan kehendak dengan merekayasa data agar terlihat normal dan sinkron. Maka munculah paham baru sebagai kritik, kritik tersebut muncul dari berbagai filsuf. Salah satu filsuf yang memberikan kritik serta mewarnai pengembangan epistimologi adalah Michael Polanyi. Kritik Polanyi terhadap paham positivisme dikarenakan paham tersebut terlalu mengagungkan ilmu pengetahuan hanya dari kacamata objektivitas semata. Yaitu, sumber pengetahuan berasal dari pengalaman yang dibuktikan kebenarannya melalui metode verivikasi yang selanjutnya dibuktikan secara empiris.

Hal tersebut membuat ilmu pengetahuan tidak berkemang. Pemikiran Polanyi ternyata memberi pencerahan pada pengembangan serta kemajuan ilmu pengetahuan setelahnya tidak terkecuali pada sisi Manajemen Pendidikan (Hasbi, 2021). Konsep Tacit Knowledge (Segi Tak Terungkap Ilmu Pengetahuan) milik Michael Polanyi membantu lembaga pendidikan menjadi lembaga yang maju dengan tidak terduga melalui penggalian potensinya yang masih tersembunyi (Ray, 2009).

\section{METODE PENELITIAN}

Sesuai dengan karakteristik masalah yang diangkat dalam penelitan ini maka menggunakan Metode Riset kualitatif, yaitu menekankan analisanya pada data deskriptif berupa kata-kata tertulis yang diamati. Pendekatan kualitatif penulis gunakan untuk menganalisis kajian aksiologi ilmu pengetahuan dan keislaman, maka dengan sendirinya penganalisaan data ini lebih difokus- kan pada Penelitian Kepustakaan (Library Research), yakni dengan membaca, menelaah dan mengkaji buku-buku dan sumber tulisan yang erat kaitannya dengan masalah yang dibahas. Metode yang digunakan dalam kajian ini menggunakan metode atau pendekatan kepustakaan (library research), menurut Zed dalam (Rahayu, 2020) bahwa studi pustaka atau kepustakaan dapat diartikan sebagai serangkaian kegiatan yang berkenaan dengan metode pengumpulan data pustaka, membaca dan mencatat serta mengolah bahan penelitian, Jenis penelitian ini adalah penelitian kualitatif. Menurut Ibnu dalam (Nasser, 2021) penelitian kualitatif adalah suatu penelitian yang datanya dinyatakan dalam bentuk verbal dan dianalisis tanpa menggunakan teknik statistik. Berdasarkan beberapa definisi penelitian kualitatif di atas, dapat disimpulkan bahwa penelitian kualitatif adalah suatu penelitian yang datanya dinyatakan dalam bentuk verbal, tidakmenggunakan angka dan analisisnya tanpa menggunakan teknik statistik.

1. Objek Penelitian

Dalam penelitian ini objek penelitian terdiri dari 2 (dua), yaitu objek formal dan objek material (Arifudin, 2020). Objek formal dalam penelitian ini berupa data yaitu data yang berhubungan dengan kajian terhadap gerakan kebangkitan epistimologi (epistimological movement) tacit knowledge Michael Polanyi. Sedangkan objek materialnya berupa sumber data, dalam hal ini adalah tinjauan kritis terhadap kajian terhadap gerakan kebangkitan epistimologi (epistimological movement) tacit knowledge Michael Polanyi.

2. Waktu Penelitian

Penelitian ini dilaksanakan pada bulan November sampai dengan Desember tahun 2021.

3. Teknik Pengumpulan Data

Analisis data tidak saja dilakukan setelah data terkumpul, tetapi sejak tahap pengumpulan data proses analisis telah dilakukan. Penulis menggunakan strategi analisis "kualitatif", strategi ini dimaksudkan bahwa analisis bertolak dari data-data dan bermuara pada kesimpulan-kesimpulan umum. Berdasarkan pada strategi analisis data ini, dalam rangka membentuk kesimpulan-kesimpulan umum analisis dapat dilakukan menggunakan kerangka pikir "induktif". Menurut (Sugiyono, 2015) bahwa metode pembahasan menggunakan metode deskriptif-analisis, yaitu menjelaskan serta mengelaborasi ide-ide utama yang berkenaan dengan topik yang dibahas. 
Kemudian menyajikannya secara kritis melalui sumber-sumber pustaka primer maupun skunder yang berkaitan dengan tema.

4. Alat Pengumpulan Data

Dalam penelitian ini, penulis akan menggunakan metode dokumentasi sebagai alat untuk pengumpul data karena penelitian ini adalah penelitian kepustakaan. Dengan kata lain, menurut (Juhji, 2020) bahwa teknik ini digunakan untuk menghimpun data-data dari sumber primer maupun sekunder.

5. Teknik Analisis Data

Analisis data tidak saja dilakukan setelah data terkumpul, tetapi sejak tahap pengumpulan data proses analisis telah dilakukan. Penulis menggunakan strategi analisis "kualitatif", strategi ini dimaksudkan bahwa analisis bertolak dari data-data dan bermuara pada kesimpulan-kesimpulan umum. Berdasarkan pada strategi analisis data ini, dalam rangka membentuk kesimpulan-kesimpulan umum analisis dapat dilakukan menggunakan kerangka pikir "induktif". Menurut (Sugiyono, 2015) bahwa metode pembahasan menggunakan metode deskriptif-analisis, yaitu menjelaskan serta mengelaborasi ide-ide utama yang berkenaan dengan topik yang dibahas. Kemudian menyajikannya secara kritis melalui sumber-sumber pustaka primer maupun skunder yang berkaitan dengan tema.

6. Prosedur Penelitian

Data pada penelitian ini dicatat, dipilih dan kemudian diklasifikasikan sesuai dengan kategori yang ada. Pendekatan yang digunakan adalah pendekatan deskriptif analitis. Menurut (Marantika, 2020) bahwa deskriptif analitis (descriptive of analyze research), yaitu pencarian berupa fakta, hasil dari ide pemikiran seseorang melalui cara mencari, menganalisis, membuat interpretasi serta melakukan generalisasi terhadap hasil penelitian yang dilakukan. Prosedur penelitian ini adalah untuk menghasilkan data deskriptif yang berupa data tertulis setelah melakukan analisis pemikiran (content analyze) dari suatu teks. Setelah penulis mengumpulkan bahan-bahan yang berhubungan dengan masalah yang akan di bahas dalam penelitian ini, kemudian penulis menganalisis dan menarasikan untuk diambil kesimpulan.

\section{HASIL DAN PEMBAHASAN}

Dalam pembahasan ini akan dibahas tentang Pengertian Aksiologi, Aksiologi dalam Islam,
Teori Nilai, Nilai dan Fakta, Ilmu, dan Pengetahuan.

1. Pengertian Aksiologi

Aksiologi menurut Bahasa berasal dari bahasa Yunani "axios" yang berarti bermanfaat, dan logos yang berarti ilmu pengetahuan atau ajaran. Secara istilah, aksiologi adalah ilmu pengetahuan yang menyelidiki hakikat nilai yang ditinjau dari sudut kefilsafatan. Sejalan dengan itu, maka aksiologi adalah studi tentang hakikat tertinggi, realitas dan arti dari nilai-nilai (kebaikan, keindahan dan kebenaran). Dengan demikian aksiologi adalah studi tentang hakikat tertinggi dari nilai-nilai etika dan estetika (Sumantri, 2005).

Menurut kamus Bahasa Indonesia aksiologi adalah kegunaan ilmu pengetahuan bagi kehidupan manusia, kajian tentang nilai-nilai khusus etika2. Suriasumantri mengatakan, aksiologi adalah teori nilai yang berkaitan dengan kegunaan dari pengetahuan yang diperoleh. Dikatakan bahwa aksiologi adalah suatu Pendidikan yang menguji dan mengintegrasikan semua nilai tersebut dalam kehidupan manusia dan menjaganya, membinanya di dalam kepribadian peserta didik (Jama, 2008), dengan demikian aksiologi adalah salah satu cabang filsafat yang mempelajari tentang nilai-nilai atau norma-norma terhadap sesuatu ilmu (Jama, 2008). Mengenai nilai itu sendiri dapat dijumpai dalam kehidupan sehari-hari seperti kata-kata adil dan tidak adil, jujur dan curang, benar dan salah, baik dan tidak baik. Hal itu semua mengandung penilaian karena manusia yang dengan perbuatannya berhasrat mencapai atau merealisasikan nilai. Nilai yang dimaksud adalah sesuatu yang dimiliki manusia untuk melakukan berbagai, pertimbangan tentang apa yang dinilai. Aksiologi ialah pengetahuan yang menyelidiki hakekat nilai, pada umumnya ditinjau dari sudut pandangan kefilsafatan.

Di dunia ini terdapat banyak cabang pengetahuan yang bersangkutan dengan masalahmasalah nilai seperti, epistemologis, etika dan estetika. Epistemologi bersangkutan dengan masalah kebenaran, etika bersangkutan dengan masalah kebaikan, dan estetika bersangkutan dengan masalah keindahan.

Aksiologi ialah ilmu pengetahuan yang menyelidiki hakekat nilai, pada umumnya ditinjau dari sudut pandangan kefilsafatan. Di dunia ini terdapat banyak cabang pengetahuan yang bersangkutan dengan masalahmasalah nilai yang khusus seperti epistim- 
ologi, etika dan estetika (Zainiyati, 2015). Epistemologi bersangkutan dengan masalah kebenaran, etika bersangkutan dengan masalah kebaikan, dan estetika bersangkutan dengan masalah keindahan.

Dari definisi-definisi aksiologi di atas, dapat di simpulkan bahwa permasalahan utama adalah mengenai nilai. Nilai yang dimaksud adalah sesuatu yang dimiliki manusia, untuk melakukan berbagai pertimbangan tentang apa yang dinilai. Teori tentang nilai yang dalam filsafat mengacu kepada permasalahan etika dan estetika, etika menilai perbuatan, manusia maka lebih tepat kalua dikatakan bahwa objek formal etika adalah normanorma, kesusilaan manusia. Dapat dikatakan pula menurut Kattsoff dalam (Arifudin, 2021) bahwa etika mempelajari tingkah laku manusia ditinjau dari segi baik dan tidak baik, di dalam suatu kondisi yang normative yaitu, suatu kondisi yang melibatkan norma-norma. Sedangkan estetika berkaitan dengan nilai tentang pengalaman keindahan yang dimiliki oleh manusia terhadap lingkungan dan fenomena di sekelilingnya.

\section{Aksiologi dalam Islam}

Aksiologi dalam islam adalah ilmu yang mempelajari tentang nilai atau etika. Etika (Akhlak) merupakan tujuan pokok bagi orang yang mempelajari ilmu itu sendiri. Sebagian lain berpendapat, bahwa ilmu adalah sebagai jalan, atau sarana untuk memperoleh etika, kemudahan-kemudahan dalam hidupnya di dunia (Na'im, 2021). Sedangkan Kontowijoyo menyebutkan aksiologi dalam paradigma islam yaitu ilmu tidak ada yang benar-benar netral. Ilmu pada dasarnya tidak ada yang bebas nilai, bisa syarat dengan kepentingan perumusannya dan pembuatnya (Kuntowijoyo., 2006). Ilmu modern yang selama ini sering di klaim sebagai bebas nilai, sehingga dapat di manfaatkan oleh siapa saja, ternyata tidak lepas dari nilai-nilai yang dianut oleh penganutnya, seperti filsafat barat.

Dalam konstruksi keilmuan islam, ilmu bekerja dalam bingkai paradigma islam itu sendiri, dimana ilmu bersumber langsung dari teks wahyu Al-quran. Maka nilai etis yang terkandung dalam ilmu keislaman berada dalam bingkai etika-moral yang sangat erat. Karena misi kenabian Muhammad SAW adalah membangun etika-moral (akhlak). Kontowiyowo menyebut Etika-Moral dengan etika Profetik. Nilai etika profetik itu sendiri berasal dari akhlak Nabi Muhammad SAW dan sumbernya adalah wahyu allah SWT (Kuntowijoyo., 2006), Oleh karena itu, ada perbedaan pendapat tentang aksiologi dalam pandangan Barat dan Islam. Pertama, menginginkan bahwa ilmu harus bersifat netral terhadap nilai-nilai baik secara ontology maupun aksiologi. Dalam hal ini, ilmuwan Barat adalah menemukan pengetahuan dan terserah pada orang lain untuk mempergunakannya, apakah ilmu tersebut digunakan untuk tujuan baik datau untuk tujuan buruk.

Kedua berpendapat bahwa netralitas ilmu terhadap nilai- nilai hanyalah terbatas pada metafisika keilmuwan, sedangkan dalam penggunaannya ilmu terletak pada objek penelitian harus dilandaskan pada asas-asas moral (Satria, 2016). Oleh karena itu, bahwa ilmu tidak ada yang benar-benar bebas nilai, tetapi sangat tergantung kepada siapa siapa yang diyakini. Sedangkan aksiologi islam, memandang bahwa ilmu itu berasal dari Allah Swt, sang maha pencipta (pemberi Nilai). Karena nilai kebaikan dan keburukan itu sejatinya adalah dari tuhan untuk manusia. Manusia yang akan memberikan nilai terhadap perilaku dan perbuatan.

\section{Teori Nilai}

Nilai sebagai sesuatu yang menarik bagi seseorang, sesuatu yang menyenangkan, sesuatu yang dicari, sesuatu yang disukai dan diinginkan. Pendeknya nilai adalah sesuatu yang baik (Hamersma, 2006). Lawan dari nilai adalah non-nilai atau disvalue. Ada yang mengatakan disvalue sebagai nilai negative, sedangkan sesuatu yang baik adalah nilai positif (Baqir, 1999). Hans Jonas, seorang filsuf Jerman-Amerika, mengatakan nilai sebagai the addresse of a yes. Sesuatu yang ditujukan dengan ya. Nilai adalah sesuatu yang kita iya-kan tau yang kita aminkan. Nilai selalu memiliki konotosi yang positif.

Ada tiga ciri yang dapat kita kenali dengan nilai, yaitu nilai yang berkaitan subjektif, praktik, dan sesuatu yang ditambahkan pada objek. Pertama, nilai berkaitan dengan subjek. Artinya nilai itu berkaitan dengan kehadiran manusia sebagai subjek. Kalo tidak manusia yang memberi nilai, nilai itu tidak akan pernah ada. Tanpa kehadiran manusia pun, kalau Meletus ya tetap Meletus. Alasannya sekarang Ketika Gunung Merapi Meletus misalnya, apakah itu sesuatu yang "indah" ataukah "membahayakan" bagi kehidupan 
manusia (Baqir, 1999). Kesemuanya itu tetap memerlukan kehadiran manusia untuk memberikan penilaian.

Dalam hal ini subjektivitas memang bergantung, semata-mata pada pengalaman manusia. Kedua nilai dalam konteks praktis yaitu subjek ingin membuat sesuatu, seperti lukisan, gerabah dan lain-lain. Ketiga berkaitan dengan nilai tambah pada objek. Nilai tambah itu dapat berupa budaya, estetis, kewajiban, kesucian, kebenaran, maupun yang lainnya (Baqir, 1999). Bisa jadi objek yang sama akan memiliki nilai yang berbeda-beda bagi perbagai subjek.

Perbedaan antara nilai sesuatu itu disebabkan sifat nilai itu sendiri. Nilai bersifat ide atau abstrak (tidak nyata). Nilai bukanlah suatu fakta yang dapat ditangkap oleh indra. Tingkah laku perbuatan manusia atau sesuatu yang mempunyai nilai itulah yang dapat ditangkap oleh indra karena ia bukan fakta yang nyata. Jika Kembali kepada ilmu pengetahuan, kita akan membahas masalah benar dan tidak benar (Riyanto, 2013). Kebenaran adalah persoalan logika dimana persoalan nilai adalah persoalan penghayatan, perasaan dan kepuasan. Ringkasan persoalan nilai, bukanlah membahas kebenaran dan kesalahan (benar dan salah) akan tetapi masalahnya ialah soal baik dan buruk, senang atau tidak senang.

Masalah kebenaran memang tidak terlepas dari nilai, tetapi nilai adalah menurut logika. Teori nilai adalah menyelesaikan masalah etika dan estetika. Teori nilai dalam filsafat mengacu pada permasalahan etika dan estetika. Etika memiliki dua arti yaitu kumpulan pengetahuan mengenai penilaian terhadap perbuatan manusia, dan predikat yang dipakai untuk membedakan perbuatan, tingkah laku atau yang lainnya (Muslih, 2016). Nilai itu bersifat objektif, tapi kadang-kadang bersifat subjektif. Dikatakan objektif, jika nilai-nilai tergantung pada subjek atau kesadaran yang menilai. Tolak ukur suatu gagasan berada pada objeknya, bukan pada subjek yang melakukan penilaian.

Kebenaran tidak tergantung pada kebenaran pada pendapat individu melainkan pada objektivitas fakta. Sebaliknya nilai menjadi subjektif, apabila subjek berperan dalam memberi penilaian; kesadaran manusia menjadi tolak ukur penilaian. Dengan demikian nilai subjektif selalu memperhatikan berbagai pandangan yang dimiliki akal budi manusia, sperti perasaan yang akan mengasah kepada suka atau tidak suka, senang atau tidak senang.

\section{Nilai dan Fakta}

Ada perbedaan antara pertimbangan fakta berbentuk kenyataan, ia dapat ditangkap dengan panca indra, sedang nilai hanya dapat dihayati walaupun para filosof berbeda pandangan tentang definisi nilai, namun pada umumnya menganggap bahwa nilai adalah pertimbangan tentang penghargaan (Muslih, 2014). Pertimbangan fakta dan pertimbangan nilai tidak dapat dipisahkan, diantara keduanya karena saling mempengaruhi. Sifat-sifat benda yang dapat diamati juga termasuk dalam penilaian. Jika fakta berubah, maka penilaian kita berubah, ini berarti pertimbangan nilai dipengaruhi oleh fakta.

Fakta itu sebenarnya netral, tetapi manusialah yang memberikan nilai kedalamannya, sehingga ia mengandung nilai. Namun bagaimanakah kriteria benda atau fakta itu mempunyai nilai. Nilai dapat dibagi menjadi dua yaitu nilai etika dan nilai estetika. Nilai etika termasuk cabang filsafat yang membicarakan perbuatan manusia dan memandangnya dari sudut baik dan buruk.

Adapun cakupan dari nilai etika adalah ukuran perbuatan yang baik yang berlaku secara universal bagi seluruh manusia, apakah dasar yang dipakai untuk menentukan adanya norma-norma universal tersebut, apakah yang dimaksud dengan pengertian baik dan buruk dalam perbuatan manusia, apakah yang dimaksud dengan kewajiban dan apakah implikasi suatu perbuatan baik dan buruk (Abidin, 2015). Nilai etika diperuntukan pada manusia saja, selain manusia (binatang, benda, alam) tidak mengandung nilai etika, karena itu tidak mungkin dihukum baik dan buruk, salah atau benar.

Adapun estetika merupakan nilai-nilai yang berhubungan dengan kreasi seni, dan pengalaman-pengalaman yang berhubungan dengan seni atau kesenian (Bairizki, 2021). Kadang estetika diartikan sebagai filsafat seni dan kadang-kadang prinsip yang berhubungan dengan estetika dinyatakan dengan keindahan. Syarat estetika terbatas pada lingkungannya, disamping juga terikat dengan ukuran-ukuran etika. Etika menuntut supaya yang bagus itu baik. Lukisan seni dapat mengandung nilai estetika, tetapi akal sehat menolaknya, karena tidak ada etika. Sehingga 
kadang orang mementingkan nilai panca indera dan mengabaikan nilai rohani. Orang hanya mencari nikmat tanpa mempersoalkan, apakah ia baik atau buruk. Nilai estetika tanpa diikat oleh ukuran etika dapat berakibat mudarat kepada estetika dan dapat merusak.

\section{Ilmu}

Ilmu adalah kumpulan pengetahuan yang telah teruji kebenarannya secara ilmiah. ilmu merupakan suatu aktifitas tertentu yang menggunakan metode tertentu untuk menghasilkan pengetahuan tertentu. Dari dua pengertian di atas dapat disimpulkan bahwa: ilmu adalah kumpulan dari pengetahuan yang diperoleh melalui kegiatan penelitian ilmiah yang hasilnya dapat $\mathrm{d}$ ipertanggungjawabkan secara ilmiah.

Dalam islam, Al-Maududi (1967) dalam bukunya Islamic Way of life menejelaskan,' kehidupan manusia harus bersinergi antara hidup di dunia dan akhirat. Dimana dalam way of Lift, bahwa sistem normal Islam itu kehidupan di dunia manusia harus berkaitan dengan agama. Manusia memiliki ciri-ciri yang komprehensif, yang senantiasa mengabdikan diri kepada Allah sebagai hamba-Nya untuk memperoleh ridha untuk kebahagiaan kelak (Al-Maududi, 1996), oleh sebab itu, ilmu harus memandang, bahwa tujuan ilmu sama dengan tujuan agama, yaitu untuk kesejahteraan umat manusia. Karena ilmu memiliki perhatian besar terhadap pendidikan jiwa manusia dan pertumbuhannya, serta menghendaki kepribadian yang luhur. Dan bahwa orang yang mencari ilmu adalah sama dengan mencari hakekat (kebenaran) (Suriasumantri, 2000), Ciri-ciri manusia lain tersebut antara lain sebagai berikut:

a) Kebahagiaan Allah adalah tujuan hidup Muslim, sumber standar moral yang tinggi dan cara evaluasi moral manusia. Sikap mencari keridhaan Allah memberikan sanksi moral untuk mencintai dan menghormatinya, yang pada gilirannya mendorong orang untuk mematuhi hukum moral tanpa paksaan dari luar. Berdasarkan keyakinan kepada Allah dan Hari Penghakiman, manusia dipaksa untuk mengikuti bimbingan moral dengan sungguh-sungguh dan jujur, sambil dengan tulus menaati Allah.

b) Semua lingkup kehidupan manusia senantiasa ditegakkan di atas moral Islami, sheingga moral tersebut berkuasa penuh atas semua urusan. Hawa nafsu clan kepenti- ngan pribadi tidak diberi kesempatan untuk menguasai kehidupan manusia. Moral Islam mementingkan keseim bangan dalam semua aspek kehidupan: individual maupun social.

c) Islam menuntut manusia agar melaksanakan sistem kehidupan yang berdarkan atas norma-norma kebajikan clan jauh dari kejahatan. Islam memerintahkan perbuatan yang ma'nifdan mengatahui perbuatan yang mungkar, bahkan manusia dituntut supaya menegakkan keadilan dan memberantas segala kejahatan

\section{Pengetahuan}

Pengetahuan adalah gejala tahunya, secara bagian perbagian, seseorang baik bersumber dari dirinya sendiri maupun orang lain mengenai sesuatu dan dasar sesuatu itu (Poedjawijatna, 2004). Segala sesuatu yang diketahui manusia disebut pengetahuan. Pengetahuan pada hakekatnya merupakan segenap apa yang kita ketahui tentang suatu objek tertentu, termasuk ke dalamnya adalah ilmu. Jadi ilmu merupakan bagian dari pengetahuan yang diketahui oleh manusia disamping berbagai pengetahuan lain seperti seni dan agama, secara aksiologi pengetahuan yang dimiliki manusia yang berupa ilmu itu digunakan untuk kepentingan manusia dalam rangka memenuhi kebutuhan manusia yang terus bertambah sesuai perkembangan zaman.

\section{SIMPULAN DAN SARAN \\ A. Simpulan}

Berdasarkan pemaparan pada penelitian ini dapat disimpulkan bahwa tidak bisa dipungkiri bagi manusia bahwa kegunaan ilmu terhadap kehidupan manusia sangat penting dan memberikan pencerahan. Aksiologi sebagai produk dari ilmu pengetahuan telah banyak mengubah kehidupan manusia di bumi. Ilmu pengetahuan tidak ada yang bebas nilai, karena sesungguhnya yang pelajari dari dari ilmu pengetahuan berasal dari tatanilai dan etika manusia. Penerapan ilmu pengetahuan sangat terkait dengan aspek moral, dan etika, nilai. Islam memandang ilmu pengetahuan tanpa etika dan moral laksana orang yang berjalan tanpa arah. Karena kehadiran islam itu sendiri untuk menyempurnakan ahlak manusia yan awalnya tidak bermoral, menjadi orang yang bermoral, manusia yang sempurna dari sifat dan pikirannya. Moral 
atau nilai berasal dari Agama, sementara ilmu pengetahuan mempelajari alam semesta dengan konotasi fisik. Relasi antara ilmu pengetahuan dan agama sangat terkait karena terciptanya alam semesta dari Allah Swt yang disebut transcendental atau metafisik (ghaib). Tuhan itu nyata meskipun tidak bisa diraba dan dilihat, tetapi adanya alam semesta ini bukti adanya Tuhan. Oleh karena itu, filsafat barat dan filsafat islam sangat berbeda. Karena objek kajiannya berbeda, filsafat islam mengenal fisik, sistematis, metafisik, sementara filsafat barat bersumber kepada fisik dan sistematis semata. Sehingga filsafat islam lebih kaya dalam khazanah ilmu penetahuan dari pada filsafat barat.

\section{B. Saran}

Pembahasan terkait penelitian aksiologi ilmu pengetahuan dan keislaman dalam penelitian ini masih sangat terbatas dan membutuhkan banyak masukan. Saran untuk penulis selanjutnya adalah mengkaji lebih dalam dan secara komprehensif terkait aksiologi ilmu pengetahuan dan keislaman.

\section{DAFTAR RUJUKAN}

Abidin. (2015). Filsafat ilmu keislaman integrative. Jurnal Ilmu Ushuludin, 13(5), 517.

Al-Maududi. (1996). Islamic Way of life. Lahore: Islamic Publication.

Arifudin, O. (2019). Manajemen Sistem Penjaminan Mutu Internal (SPMI) Sebagai Upaya Meningkatkan Mutu Perguruan Tinggi. MEA (Manajemen, Ekonomi, \& Akuntansi), 3(1), 161-169.

Arifudin, 0. (2020). Psikologi Pendidikan (Tinjauan Teori Dan Praktis). Bandung: Widina Bhakti Persada.

Arifudin, O. (2021). Media Pembelajaran Pendidikan Anak Usia Dini. Bandung: Widina Bhakti Persada.

Bahri, A. S. (2021). Pengantar Penelitian Pendidikan (Sebuah Tinjauan Teori dan Praktis). Bandung: Widina Bhakti Persada.

Bairizki, A. (2021). Manajemen Perubahan. Bandung : Widina Bhakti Persada.
Baqir. (1999). Falsafatuna terhadap Belbagai Aliran Filsafat Dunia, Cet. VII. Bandung: Mizan.

Fathirma'ruf, F., \& M. Said, B. (2020). Pengembangan Perangkat Pembelajaran Konstruktivistik Model Teaching with Analogies (TWA) pada Mata Kuliah Database Management System (DBMS) untuk Meningkatkan Kemampuan Berpikir Kreatif Mahasiwa. Jurnal Teknologi Informasi dan Ilmu Komputer, 7(5), 10511060 .

doi:http://dx.doi.org/10.25126/jtiik.20207 52388

Hamersma. (2006). Pintu Masuk ke Dunia Filsafat. Yogyakarta: Kanisius.

Hanafiah, H. (2021). Pelatihan Software Mendeley Dalam Peningkatan Kualitas Artikel Ilmiah Bagi Mahasiswa. Jurnal Karya Abdi Masyarakat, 5(2), 213-220.

Imansyah, M. N., \& Asmedy, A. (2021). Akselerasi covid-19 pada proses pembelajaran di era pendidikan 4.0. JPPI (Jurnal Penelitian Pendidikan Indonesia), 7(2), 279-284.

Irwansyah, R. (2021). Perkembangan Peserta Didik. Bandung : Widina Bhakti Persada.

Jama. (2008). Filsafat Ilmu. Padang: Program Pascasarjana Universitas Negeri Padang.

Juhji. (2020). Manajemen Humas Sekolah. Bandung: Widina Bhakti Persada.

Kuntowijoyo. (2006). Islam Sebagai Ilmu: Epistemologi, Metodologi, dan Etika. Yogyakarta: Tiara Wacana.

Marantika, N. (2020). Manajemen Humas Sekolah. Bandung: Widina Bhakti Persada Bandung.

Muslih. (2014). Pengantar Ilmu Filsafat. Ponorogo : Darussaam University Press.

Muslih. (2016). Filsafat Ilmu, Kajian atas asumsi dasar, paradigma dan kerangka teori ilmu pengetahuan. Yogyakarta: LESFI.

Na'im, Z. (2021). Manajemen Pendidikan Islam. Bandung : Widina Bhakti Persada. 
Nasser, A. A. (2021). Sistem Penerimaan Siswa Baru Berbasis Web Dalam Meningkatkan Mutu Siswa Di Era Pandemi. Biormatika: Jurnal Ilmiah Fakultas Keguruan Dan Ilmu Pendidikan, 7(1), 100-109.

Poedjawijatna. (2004). Pengantar ke Ilmu dan Filsafat. Jakarta : Rineka Cipta.

Rahayu, Y. N. (2020). Program Linier (Teori Dan Aplikasi). Bandung : Widina Bhakti Persada.

Riyanto. (2013). Integrasi-Interkoneksi Keilmuan; Biografi Intelektual M. Amin Abdullah (1953...) Person, Knowledge, and Institution. Yogyakarta: SUKA Press.

Satria. (2016). Hakikat ilmu: Ontologi, Epistimologi dan Aksiologi. Jurnal UINSU, 3(3), 5-112.

Sugiyono. (2015). Metode Penelitian Pendidikan (Pendekatan Kuantitatif,. Kualitatif dan $R \& D)$. Bandung : CV. Alfabeta.
Sumantri. (2005). Filsafat ilmu, sebuah pengantar popular. Jakarta: Sinar harapan.

Suriasumantri. (2000). Filsafat Ilmu Sebuah Pengantar Populer. Jakarta: Pustaka Sinar Harapan.

Tanjung, R. (2021). Kompetensi Manajerial Kepala Sekolah Dalam Meningkatkan Kinerja Guru Sekolah Dasar. JIIP-Jurnal Ilmiah Ilmu Pendidikan, 4(4), 291-296. https://doi.org/10.54371/jiip.v4i4.272

Zainiyati. (2015). Landasan Fondasional Integrasi Keilmuan di UIN Maulana Malik Ibrahim Malang dan UIN Sunan Ampel Surabaya. Islamica: Jurnal Studi Keislaman., 3(1), 78-88. 